\title{
Cancer incidence attributable to alcohol consumption in Alberta in 2012
}

\author{
Anne Grundy PhD, Abbey E. Poirier MSc, Farah Khandwala MSc, Alison McFadden BScH, \\ Christine M. Friedenreich PhD, Darren R. Brenner PhD
}

See also www.cmajopen.ca/lookup/doi/10.9778/cmajo.20150068

Abstract

Background: Alcohol consumption has been associated with risk of oral cavity/pharyngeal, laryngeal, esophageal, liver, colorectal and breast cancers. The purpose of this study was to estimate the proportion and total number of these cancers in Alberta in 2012 attributable to alcohol consumption.

Methods: We estimated cancers attributable to alcohol consumption in adults in Alberta using population attributable risk calculations. Relative risks were obtained from recent meta-analyses, and alcohol consumption in Alberta was quantified with the use of data from the Canadian Community Health Survey. We obtained age-, site- and sex-specific cancer incidence data for 2012 from the Alberta Cancer Registry. The impact of potential underestimation of alcohol consumption in Canadian Community Health Survey data was evaluated with the use of per-capita alcohol sales data from Statistics Canada.

Results: Proportions of cancers attributable to alcohol consumption at individual cancer sites were estimated to be as low as $5.1 \%$ (liver) and as high as $19.9 \%$ (oral cavity/pharynx) among men and as low as $2.1 \%$ (liver) and as high as $7.6 \%$ (oral cavity/pharynx) among women in Alberta. The total number of alcohol-attributable cancer cases was highest for common cancers (colorectal, female breast), whereas at individual cancer sites, population attributable risks were highest for upper aerodigestive tract cancers. A total of $4.8 \%$ of alcohol-associated cancers (1.6\% of all cancers) in Alberta could be attributed to alcohol consumption. After adjustment for recorded alcohol consumption, our estimates of population attributable risk increased to $10.7 \%$ of alcohol-associated cancers and $3.5 \%$ of all cancers.

Interpretation: Alcohol consumption is estimated to account for $1.6 \%-3.5 \%$ of total cancer cases in Alberta. Given that no level of alcohol consumption is considered safe with respect to cancer risk, strategies to reduce alcohol consumption have the potential to reduce Alberta's cancer burden.

\begin{abstract}
n 1988, alcohol consumption was classified as carcinogenic to humans by the International Agency for L Research on Cancer, ${ }^{1}$ which specifically cited "sufficient evidence" for cancers of the oral cavity, pharynx, larynx, esophagus and liver. In 2010, an updated review by the agency identified additional evidence sufficient to support a carcinogenic role for alcohol consumption in cancers of the colorectum and female breast in addition to the previously mentioned cancer sites. ${ }^{2}$ These classifications are similar to those in the 2007 World Cancer Research Fund report, in which a "convincing increased risk" with alcohol consumption was described for cancers of the mouth, pharynx, larynx, esophagus, breast and colorectum in men and a "probable
\end{abstract}

increased risk" described for cancers of the liver and colorectum in women. ${ }^{3}$

The specific mechanism through which alcohol influences cancer risk remains unknown. Hypothesized pathways include

Competing interests: None declared.

This article has been peer reviewed.

Correspondence to: Darren Brenner, Darren.Brenner@ albertahealthservices.ca

CMAJ Open 2016. DOI:10.9778/cmajo.20160070 
actions of the alcohol metabolite acetaldehyde and the potential for alcohol to work as a solvent for other carcinogens. ${ }^{4}$ However, even in the absence of specific mechanistic understanding, given the established relations between alcohol consumption and cancer risk, understanding the cancer burden associated with alcohol consumption is relevant to the planning of cancer prevention programs and interventions. An estimate of this burden was recently completed for Ontario. ${ }^{5}$ The purpose of this investigation was to quantify the proportion and absolute number of cancers diagnosed in 2012 in adults in Alberta that could be attributable to previous consumption of alcoholic beverages.

\section{Methods}

This article is part of a series of exposure-specific reports concerning the proportion of cancer cases attributable to modifiable lifestyle and environmental risk factors in the general population of Alberta. The methodologic framework for the series has previously been described. ${ }^{6}$

\section{Latency period}

The effect of alcohol on cancer risk is understood to be the result of past exposure. Therefore, we identified a biologically meaningful latency period for each cancer site by examining published prospective cohort studies that had investigated the association between alcohol consumption at baseline and followed the study participants for cancer incidence. We considered the theoretical latency period to be the time between initiation of exposure and cancer diagnosis, and the measured latency period to be the time between exposure measurement and cancer diagnosis. ${ }^{6}$ For the alcohol-specific analyses described here, to select appropriate prevalence data related to alcohol consumption in Alberta, we attempted to quantify the measured latency period from existing high-quality cohort studies and subsequently refer to this simply as the "latency period." Latency periods of 11-12 years for breast, colorectal, oral cavity and pharynx, and esophagus cancers and of 8-9 years for larynx and liver cancers were identified as the appropriate periods for cancers to occur within these highquality cohort studies. ${ }^{7-21} \mathrm{We}$ chose prevalence estimates corresponding to the midpoint of the latency period suggested by cohort studies as the appropriate period between alcohol exposure and cancer diagnosis. ${ }^{6}$ To estimate the number of alcohol-attributable cancer cases in Alberta for 2012, we used Canadian Community Health Survey data from cycle 1.1 (2000-2001) for an 11-12 year latency period (breast, colorectal, oral cavity and pharynx, and esophagus cancers) and data from cycle 2.1 (2003) for an 8-9 year latency period (larynx and liver cancers). ${ }^{22}$

\section{Prevalence of exposure}

We obtained estimates of the prevalence of alcohol consumption in Alberta using data from the Canadian Community Health Survey, applying the methods described by Cancer Care Ontario. ${ }^{5}$ Details of the methods used for the Canadian Community Health Survey were published previously. ${ }^{22}$
Based on responses to the following 3 alcohol-related questions, respondents were categorized into 1 of 15 alcohol consumption categories (Table 1), focused primarily on frequency of consumption: ${ }^{5}$

1. Thinking back over the past week, did you have a drink of beer, wine, liquor or any other alcoholic beverage? If yes, how many drinks did you have on each day?

2. During the past 12 months, how often did you drink alcoholic beverages?

3. Have you ever had a drink? If yes, did you ever regularly drink more than 12 drinks in a week? (Respondents were asked this question only if they reported not drinking during the previous 12 months.)

We then estimated the number of drinks per day consumed in each category as in the Technical Appendix to the Cancer Care Ontario report. ${ }^{5}$ Briefly, for categories 1-5, the median number of drinks reported by respondents from each category was assigned to estimate consumption. We estimated consumption levels for categories $6-12$ by first estimating the number of drinks per week using data on consumption in the previous 12 months for respondents who did report drinking in the previous week. The following adjustments were then applied: for category 6, the median number of drinks per drinking occasion was divided by 60 to reflect drinking once every 2 months; for category 7 , the median number of drinks was divided by 30 to reflect drinking once per month; for category 8 , the median number of drinks per drinking occasion was multiplied by 2.5 and divided by 30 to reflect drinking 2 to 3 times per month; for category 9 , the median number of drinks was divided by 7 to reflect drinking once per week; for category 10, the median number of drinks was multiplied by 2.5 and divided by 7 to reflect drinking 2 to 3 times per week; and for category 11 , the median number of drinks was multiplied by 5 and divided by 7 to reflect drinking 5 times per week. Respondents who reported having 13 drinks per week (or 1.9 per day) were assigned to category 13 , and category 14 was assigned the same quantity as category 6 . We then converted values for each category of drinks per day to grams per day based on the standard $13.6 \mathrm{~g}$ of ethanol/drink in Canada. ${ }^{23}$ The proportion of the population in each alcohol consumption category is shown in Table 1 , and the estimated number of grams per day of alcohol is shown in Table 2, stratified by age and sex.

\section{Risk estimates}

We conceptualized the risk of cancer at individual sites associated with alcohol consumption as the increase in risk per gram per day of alcohol consumption. ${ }^{24}$ Specific risks obtained from Parkin's ${ }^{24}$ publication (themselves obtained from meta-analyses and pooling projects) are shown in Table 3 .

\section{Statistical analysis}

We estimated population attributable risks for cancer in Alberta associated with alcohol consumption using methods similar to those used by Parkin $^{24}$ and a more recent Cancer 
Care Ontario 5 analysis. Population attributable risks were estimated for oral cavity and pharynx, larynx, esophagus, liver, breast and colon cancers with the use of equation 1, incorporating the multiple levels of alcohol exposure.

Equation 1: $P A R=\left(P e_{1} \times E R R_{1}\right)+\left(P e_{2} \times E R R_{2}\right)+\ldots+\left(P e_{x}\right.$ $\left.\times E R R_{x}\right) /\left(1+\left(\left(P e_{1} \times E R R_{1}\right)+\left(P e_{2} \times E R R_{2}\right)+\ldots+\left(P e_{x} \times\right.\right.\right.$ $\left.\left.E R R_{x}\right)\right)$ ) where $P A R=$ population attributable risk, $P e_{x}$ represents the proportion of the population in alcohol consumption category $x$, and $E R R_{x}$ represents the excess relative risk $\left(R R_{x}-1\right)$ in each of the 15 alcohol consumption categories. We calculated ERRs for each category according to Parkin, ${ }^{24}$ using equation 2:

Equation 2: $E R R_{x}=\exp \left(R_{x} \times G_{x}\right)-1$

Table 1: Proportion of Alberta adults in each alcohol consumption category, by sex and age

\begin{tabular}{|c|c|c|c|c|c|c|c|c|}
\hline \multirow[b]{3}{*}{ Consumption category } & \multicolumn{8}{|c|}{ Age, yr; $\%$ of Albertans ( $95 \%$ confidence interval) } \\
\hline & \multicolumn{4}{|c|}{ Men } & \multicolumn{4}{|c|}{ Women } \\
\hline & $20-34$ & $35-49$ & $50-64$ & $\geq 65$ & $20-34$ & $35-49$ & $50-64$ & $\geq 65$ \\
\hline $\begin{array}{l}\text { 1. Drank during past } \\
\text { week: average } \leq 1 \\
\text { drink/d }\end{array}$ & $\begin{array}{c}34.4 \\
(31.3-37.5)\end{array}$ & $\begin{array}{c}37.8 \\
(34.9-40.8)\end{array}$ & $\begin{array}{c}34.6 \\
(30.7-38.5)\end{array}$ & $\begin{array}{c}32.4 \\
(28.2-36.6)\end{array}$ & $\begin{array}{c}30.6 \\
(27.5-33.6)\end{array}$ & $\begin{array}{c}33.9 \\
(31.1-36.7)\end{array}$ & $\begin{array}{c}32.0 \\
(28.3-35.6)\end{array}$ & $\begin{array}{c}21.5 \\
(18.3-24.8)\end{array}$ \\
\hline $\begin{array}{l}\text { 2. Drank during past } \\
\text { week: average } 1-2 \\
\text { drinks/d }\end{array}$ & $\begin{array}{c}14.3 \\
(12.0-16.6)\end{array}$ & $\begin{array}{c}13.8 \\
(11.4-16.1)\end{array}$ & $\begin{array}{c}9.1 \\
(6.9-11.3)\end{array}$ & $\begin{array}{c}7.3 \\
(4.8-9.8)\end{array}$ & $\begin{array}{c}5.8 \\
(4.3-7.4)\end{array}$ & $\begin{array}{c}5.7 \\
(4.3-7.1)\end{array}$ & $\begin{array}{c}3.8 \\
(2.1-5.4)\end{array}$ & $\begin{array}{c}1.5 \\
(0.6-2.3)\end{array}$ \\
\hline $\begin{array}{l}\text { 3. Drank during past } \\
\text { week: average } 2-3 \\
\text { drinks/d }\end{array}$ & $\begin{array}{c}5.3 \\
(4.0-6.7)\end{array}$ & $\begin{array}{c}3.4 \\
(2.2-4.5)\end{array}$ & $\begin{array}{c}4.3 \\
(2.5-6.1)\end{array}$ & $\begin{array}{c}1.7 \\
(0.7-2.7)\end{array}$ & $\begin{array}{c}1.2 \\
(0.5-2.0)\end{array}$ & $\begin{array}{c}1.1 \\
(0.5-1.8)\end{array}$ & $\begin{array}{c}0.9 \\
(0.2-1.7)\end{array}$ & $\begin{array}{c}0 \\
(0-0.1)\end{array}$ \\
\hline $\begin{array}{l}\text { 4. Drank during past } \\
\text { week: average 3-4 } \\
\text { drinks/d }\end{array}$ & $\begin{array}{c}3.5 \\
(2.3-4.7)\end{array}$ & $\begin{array}{c}1.4 \\
(0.7-2.2)\end{array}$ & $\begin{array}{c}1.3 \\
(0.6-2.0)\end{array}$ & $\begin{array}{c}0.3 \\
(0-0.8)\end{array}$ & $\begin{array}{c}0.5 \\
(0.1-0.9)\end{array}$ & $\begin{array}{c}0.7 \\
(0.2-1.2)\end{array}$ & $\begin{array}{c}0.1 \\
(0-0.3)\end{array}$ & $\begin{array}{c}0.3 \\
(0-0.8)\end{array}$ \\
\hline $\begin{array}{l}\text { 5. Drank during past } \\
\text { week: average } \geq 4 \\
\text { drinks/d }\end{array}$ & $\begin{array}{c}3.5 \\
(2.3-4.7)\end{array}$ & $\begin{array}{c}1.9 \\
(1.1-2.6)\end{array}$ & $\begin{array}{c}0.7 \\
(0-1.4)\end{array}$ & $\begin{array}{c}1.0 \\
(0-2.1)\end{array}$ & $\begin{array}{c}0.4 \\
(0-0.8)\end{array}$ & $\begin{array}{c}0.4 \\
(0-0.8)\end{array}$ & $\begin{array}{c}0.2 \\
(0-0.4)\end{array}$ & $\begin{array}{c}0 \\
(0-0)\end{array}$ \\
\hline $\begin{array}{l}\text { 6. No drinking past } \\
\text { week but drank during } \\
\text { past year } \leq 1 \text { time } / \mathrm{mo}\end{array}$ & $\begin{array}{c}10.8 \\
(8.5-13.0)\end{array}$ & $\begin{array}{c}10.8 \\
(8.8-12.8)\end{array}$ & $\begin{array}{c}14.4 \\
(11.3-17.5)\end{array}$ & $\begin{array}{c}17.2 \\
(13.4-21.0)\end{array}$ & $\begin{array}{c}22.8 \\
(19.8-25.8)\end{array}$ & $\begin{array}{c}20.2 \\
(17.7-22.6)\end{array}$ & $\begin{array}{c}20.6 \\
(17.2-24.0)\end{array}$ & $\begin{array}{c}23.0 \\
(19.7-26.4)\end{array}$ \\
\hline $\begin{array}{l}\text { 7. No drinking past week } \\
\text { but drank during past } \\
\text { year } 1 \text { time } / \mathrm{mo}\end{array}$ & $\begin{array}{c}5.3 \\
(3.8-6.7)\end{array}$ & $\begin{array}{c}5.8 \\
(4.4-7.1)\end{array}$ & $\begin{array}{c}4.6 \\
(3.1-6.0)\end{array}$ & $\begin{array}{c}3.8 \\
(2.2-5.5)\end{array}$ & $\begin{array}{c}8.5 \\
(6.8-10.3)\end{array}$ & $\begin{array}{c}6.2 \\
(4.7-7.7)\end{array}$ & $\begin{array}{c}4.9 \\
(2.9-6.8)\end{array}$ & $\begin{array}{c}3.5 \\
(2.3-4.8)\end{array}$ \\
\hline $\begin{array}{l}\text { 8. No drinking past } \\
\text { week but drank during } \\
\text { past year } 2-3 \text { times/mo }\end{array}$ & $\begin{array}{c}5.3 \\
(4.0-6.6)\end{array}$ & $\begin{array}{c}5.2 \\
(3.9-6.5)\end{array}$ & $\begin{array}{c}5.4 \\
(3.5-7.4)\end{array}$ & $\begin{array}{c}2.0 \\
(0.8-3.3)\end{array}$ & $\begin{array}{c}6.2 \\
(4.7-7.8)\end{array}$ & $\begin{array}{c}5.2 \\
(3.8-6.5)\end{array}$ & $\begin{array}{c}3.4 \\
(2.1-4.6)\end{array}$ & $\begin{array}{c}3.0 \\
(1.6-4.5)\end{array}$ \\
\hline $\begin{array}{l}\text { 9. No drinking past } \\
\text { week but drank during } \\
\text { past year } 1 \text { time/w }\end{array}$ & $\begin{array}{c}3.5 \\
(2.4-4.5)\end{array}$ & $\begin{array}{c}3.0 \\
(2.0-4.0)\end{array}$ & $\begin{array}{c}2.3 \\
(1.3-3.8)\end{array}$ & $\begin{array}{c}2.2 \\
(1.1-3.3)\end{array}$ & $\begin{array}{c}3.1 \\
(2.0-4.2)\end{array}$ & $\begin{array}{c}2.7 \\
(1.8-3.6)\end{array}$ & $\begin{array}{c}2.0 \\
(1.0-3.0)\end{array}$ & $\begin{array}{c}1.3 \\
(0.4-2.2)\end{array}$ \\
\hline $\begin{array}{l}\text { 10. No drinking past } \\
\text { week but drank during } \\
\text { past year } 2-3 \text { times/w }\end{array}$ & $\begin{array}{c}2.3 \\
(1.2-3.3)\end{array}$ & $\begin{array}{c}1.7 \\
(1.0-4.0)\end{array}$ & $\begin{array}{c}1.5 \\
(0.6-2.4)\end{array}$ & $\begin{array}{c}1.4 \\
(0.2-2.6)\end{array}$ & $\begin{array}{c}1.3 \\
(0.7-2.0)\end{array}$ & $\begin{array}{c}0.8 \\
(0.3-1.2)\end{array}$ & $\begin{array}{c}1.7 \\
(0.5-2.9)\end{array}$ & $\begin{array}{c}0.6 \\
(0.1-1.2)\end{array}$ \\
\hline $\begin{array}{l}\text { 11. No drinking past } \\
\text { week but drank during } \\
\text { past year 4-6 times/w }\end{array}$ & $\begin{array}{c}0 \\
(0-0.1)\end{array}$ & $\begin{array}{c}0.1 \\
(0-0.3)\end{array}$ & $\begin{array}{c}0.1 \\
(0-0.3)\end{array}$ & $\begin{array}{c}0.6 \\
(0-1.4)\end{array}$ & $\begin{array}{c}0 \\
(0-0)\end{array}$ & $\begin{array}{c}0 \\
(0-0.1)\end{array}$ & $\begin{array}{c}0 \\
(0-0)\end{array}$ & $\begin{array}{c}0.2 \\
(0-0.5)\end{array}$ \\
\hline $\begin{array}{l}\text { 12. No drinking past } \\
\text { week but drank during } \\
\text { past year every day }\end{array}$ & $\begin{array}{c}0.2 \\
(0-0.4)\end{array}$ & $\begin{array}{c}0.2 \\
(0-0.4)\end{array}$ & $\begin{array}{c}0.4 \\
(0-1.0)\end{array}$ & $\begin{array}{c}0.6 \\
(0-1.3)\end{array}$ & $\begin{array}{c}0.1 \\
(0-0.1)\end{array}$ & $\begin{array}{c}0.1 \\
(0-0.1)\end{array}$ & $\begin{array}{c}0.8 \\
(0-1.7)\end{array}$ & $\begin{array}{c}0.1 \\
(0-0.2)\end{array}$ \\
\hline $\begin{array}{l}\text { 13. Has had } \geq 1 \text { drink in } \\
\text { lifetime: used to } \\
\text { regularly drink }>12 \\
\text { drinks/w }\end{array}$ & $\begin{array}{c}1.4 \\
(0.7-2.1)\end{array}$ & $\begin{array}{c}4.4 \\
(3.1-5.6)\end{array}$ & $\begin{array}{c}6.5 \\
(4.7-8.2)\end{array}$ & $\begin{array}{c}6.5 \\
(4.5-8.5)\end{array}$ & $\begin{array}{c}0.8 \\
(0.3-1.3)\end{array}$ & $\begin{array}{c}1.7 \\
(0.9-2.5)\end{array}$ & $\begin{array}{c}1.8 \\
(0.9-2.7)\end{array}$ & $\begin{array}{c}1.6 \\
(0.6-2.7)\end{array}$ \\
\hline $\begin{array}{l}\text { 14. Has had } \geq 1 \text { drink in } \\
\text { lifetime: did not regularly } \\
\text { drink }>12 \text { drinks/w }\end{array}$ & $\begin{array}{c}3.2 \\
(2.1-4.3)\end{array}$ & $\begin{array}{c}4.0 \\
(2.9-5.1)\end{array}$ & $\begin{array}{c}6.6 \\
(4.8-8.5)\end{array}$ & $\begin{array}{c}14.0 \\
(10.9-17.0)\end{array}$ & $\begin{array}{c}7.8 \\
(6.2-9.4)\end{array}$ & $\begin{array}{c}12.3 \\
(10.3-14.3)\end{array}$ & $\begin{array}{c}15.9 \\
(13.2-18.7)\end{array}$ & $\begin{array}{c}28.2 \\
(24.6-31.7)\end{array}$ \\
\hline 15. Lifetime abstainer & $\begin{array}{c}4.3 \\
(2.8-5.9)\end{array}$ & $\begin{array}{c}3.8 \\
(2.4-5.2)\end{array}$ & $\begin{array}{c}4.8 \\
(2.0-7.6)\end{array}$ & $\begin{array}{c}5.8 \\
(3.6-8.0)\end{array}$ & $\begin{array}{c}9.0 \\
(6.5-11.6)\end{array}$ & $\begin{array}{c}7.6 \\
(5.6-9.6)\end{array}$ & $\begin{array}{c}10.2 \\
(6.8-13.6)\end{array}$ & $\begin{array}{c}13.5 \\
(11.0-16.1)\end{array}$ \\
\hline
\end{tabular}


Table 2: Estimated quantities of alcohol consumed for alcohol consumption categories, by age and sex

\begin{tabular}{|c|c|c|c|c|c|c|c|c|}
\hline \multirow[b]{3}{*}{ Consumption category } & \multicolumn{8}{|c|}{ Age, yr; quantities consumed, grams/d } \\
\hline & \multicolumn{4}{|c|}{ Men } & \multicolumn{4}{|c|}{ Women } \\
\hline & $20-34$ & $35-49$ & $50-64$ & $\geq 65$ & 20-34 & $35-49$ & $50-64$ & $\geq 65$ \\
\hline 1 & 5.4 & 5.4 & 5.4 & 4.1 & 4.1 & 4.1 & 4.1 & 2.7 \\
\hline 2 & 19.0 & 19.0 & 19.0 & 20.4 & 17.7 & 17.7 & 17.7 & 25.8 \\
\hline 3 & 32.6 & 32.6 & 32.6 & 32.6 & 32.6 & 36.7 & 36.7 & 28.6 \\
\hline 4 & 46.2 & 44.9 & 47.6 & 46.2 & 42.2 & 43.5 & 47.6 & 53.0 \\
\hline 5 & 80.2 & 73.4 & 69.4 & 62.6 & 61.2 & 63.9 & 0 & 0 \\
\hline 6 & 0.4 & 0.3 & 0.3 & 0.3 & 0.1 & 0.3 & 0.1 & 0.3 \\
\hline 7 & 1.2 & 0.7 & 0.4 & 0.3 & 0.8 & 0.4 & 0.3 & 0.4 \\
\hline 8 & 2.7 & 1.4 & 1.4 & 0.8 & 1.4 & 1.4 & 1.4 & 1.1 \\
\hline 9 & 4.1 & 4.1 & 2.7 & 1.4 & 4.1 & 1.4 & 2.7 & 1.4 \\
\hline 10 & 15.0 & 10.9 & 9.5 & 6.8 & 9.5 & 9.5 & 6.8 & 6.8 \\
\hline 11 & 40.8 & 28.6 & 19.0 & 9.5 & 27.2 & 17.7 & 12.2 & 9.5 \\
\hline 12 & 34.0 & 31.3 & 25.8 & 19.0 & 15.0 & 17.7 & 17.7 & 13.6 \\
\hline 13 & 25.8 & 25.8 & 25.8 & 25.8 & 25.8 & 25.8 & 25.8 & 25.8 \\
\hline 14 & 0.4 & 0.3 & 0.3 & 0.3 & 0.3 & 0.3 & 0.1 & 0.3 \\
\hline 15 & 0 & 0 & 0 & 0 & 0 & 0 & 0 & 0 \\
\hline
\end{tabular}

\begin{tabular}{|c|c|c|c|}
\hline \multicolumn{4}{|c|}{$\begin{array}{l}\text { Table 3: Risk associated with } 1 \mathrm{~g} / \mathrm{d} \text { of alcohol consumption for individual cancer } \\
\text { sites }^{24}\end{array}$} \\
\hline Cancer site & Source & Sex & $\begin{array}{l}\text { Increase in risk per } \\
\text { gram } / \mathrm{d}\left(95 \% \mathrm{Cl}^{\star}\right)\end{array}$ \\
\hline Breast & $\begin{array}{l}\text { Hamajima et al., } \\
2002^{25}\end{array}$ & Women & 0.0071 (SE 0.0008) \\
\hline $\begin{array}{l}\text { Oral cavity and } \\
\text { pharynx }\end{array}$ & Corrao et al., ${ }^{26} 2004$ & $\begin{array}{l}\text { Women and } \\
\text { men }\end{array}$ & $0.0185(0.0177-0.0200)$ \\
\hline Larynx & Corrao et al., ${ }^{26} 2004$ & $\begin{array}{l}\text { Women and } \\
\text { men }\end{array}$ & $0.0136(0.0124-0.0148)$ \\
\hline Esophagus & Corrao et al., ${ }^{26} 2004$ & $\begin{array}{l}\text { Women and } \\
\text { men }\end{array}$ & $0.0129(0.0121-0.0136)$ \\
\hline Liver & Corrao et al. ${ }^{26} 2004$ & $\begin{array}{l}\text { Women and } \\
\text { men }\end{array}$ & $0.0059(0.0041-0.0079)$ \\
\hline Colorectum & Ferrari et al., ${ }^{27} 2007$ & $\begin{array}{l}\text { Women and } \\
\text { men }\end{array}$ & $0.0058(0.0033-0.0082)$ \\
\hline
\end{tabular}

where $R_{x}$ represents the excess risk per gram of alcohol intake and $G_{x}$ represents the intake of alcohol in grams for consumption category $x$ (Table 2).

To estimate $95 \%$ confidence intervals around population attributable risk estimates, we used Monte Carlo simulation methods wherein the relative risk estimates were drawn from a $\log$ normal distribution, prevalence estimates were drawn from a binomial distribution, and incidence estimates were drawn from a Poisson distribution. Parameters for the distributions were defined by reported point estimates and confidence intervals. We drew 10000 samples and used the 2.5th and 97.5 th percentiles of the resulting population attributable risk distribution as the lower and upper limits of a $95 \%$ confidence interval. ${ }^{28,29}$ Wherever possible and when appropriate, we performed these estimations for individual sex and age groups. 


\section{Cancer incidence}

To estimate the total number of cancers attributable to alcohol consumption at each site overall and by age and sex, we applied population attributable risks to cancer incidence data obtained from the Alberta Cancer Registry for 2012. We applied a lag period of 10 years to the age groups used for cancer incidence data. Hence, for example, for people exposed to alcohol at age 20-34 years, cancer incidence data for ages 30-44 years were used. We chose the 10-year lag period to allow for consistent age groups across cancer sites, since it was the midpoint of the 2 latency periods used in this analysis.

\section{Sensitivity analysis}

Measures of alcohol consumption in population surveys can underestimate alcohol consumption, as measured by per-capita consumption levels, by as much as $30 \%-70 \% .{ }^{30}$ Furthermore, an Ontario study showed that unrecorded alcohol consumption not accounted for in per-capita sales data was $19.5 \%$ of recorded consumption. ${ }^{31}$ To examine the impact of potential underestimation of alcohol consumption in Alberta as measured by Canadian Community Health Survey data, we performed 2 separate sensitivity analyses. First, we estimated the coverage rate using the formula described by Cancer Care Ontario, ${ }^{5}$ where total per-capita consumption was characterized as total recorded consumption based on Statistics Canada alcohol sales data in Alberta, as, to our knowledge, the proportion of unrecorded alcohol consumption in Alberta has not been estimated. In the second sensitivity analysis, we applied the proportion of unrecorded alcohol consumption in Ontario to Alberta data, again estimating the coverage rate using the formula described by Cancer Care Ontario. ${ }^{5}$ We then used the estimated coverage rates to adjust estimates of the prevalence of alcohol consumption used in the estimation of population attributable risks. ${ }^{5}$

\section{Results}

\section{Prevalence of alcohol consumption}

The proportions of men and women who exceeded cancer prevention guidelines (no more than 2 drinks per day for men and 1 per day for women ${ }^{3}$ ) were similar, at $8.0 \%$ and $7.8 \%$, respectively. These proportions generally decreased with increasing age: the highest proportion of men exceeding the guideline, $12.6 \%$, was seen among those aged 20-34 years, and the highest proportion of women exceeding the guideline, $9.7 \%$, was among those aged $35-49$ years.

\section{Cancer site-specific population attributable risks}

Across all cancer sites, population attributable risks of cancer related to alcohol consumption were higher in men than in women (Table 4). In both men and women, the highest values were seen for cancers of the oral cavity and pharynx $(15.8 \%-$ $27.5 \%$ in men, $4.6 \%-10.3 \%$ in women), and overall population attributable risks were higher for cancers of the upper aerodigestive tract (oral cavity and pharynx, larynx and esophagus). Despite relatively lower population attributable risks compared with other cancer sites, the largest numbers of cancers attributable to alcohol consumption were seen for colorectal cancer in men and breast cancer in women, because the overall incidence of these cancers is higher than that of other cancers.

\section{Overall population attributable risks}

A total of 247 cancer cases in Alberta in 2012 could be attributable to alcohol consumption (Table 5), which represents $4.8 \%$ of all alcohol-associated cancers and $1.6 \%$ of all cancers diagnosed. When alcohol consumption was adjusted for survey undercoverage, the number of attributable cases increased substantially, to 547 , representing $10.7 \%$ of all alcoholassociated cancers and $3.5 \%$ of all cancers diagnosed in Alberta in 2012 (supplementary Tables S1 and S2, Appendix 1, available at www.cmajopen.ca/content/4/3/E507/suppl/ DC1). When we further adjusted these figures for unrecorded alcohol consumption using the approximation based on Ontario data, ${ }^{31}$ the number of attributable cases increased to 670 (supplementary Tables S3 and S4, Appendix 1), representing $13.1 \%$ of all alcohol-associated cancers and $4.2 \%$ of all cancers diagnosed in Alberta in 2012.

\section{Interpretation}

We estimate that $1.6 \%$ of cancers in Alberta in 2012 were attributable to alcohol consumption. This estimate increased to $4.2 \%$ after we adjusted for underestimation of alcohol consumption in Canadian Community Health Survey data using estimates of both recorded and unrecorded consumption. These proportions were higher in men $(1.8 \%-5.0 \%)$ than in women $(1.3 \%-3.4 \%)$. Population attributable risks for individual cancer sites were highest for upper aerodigestive tract cancers.

These findings are consistent with those in previous studies conducted in Ontario ${ }^{5}$ and the United Kingdom. ${ }^{24}$ In Ontario, $2 \%-4 \%$ of cancers could be attributed to alcohol consumption; the upper end of this estimate represents the same adjustment for underestimation of alcohol consumption as that used in our analysis. ${ }^{5}$ As in our study, whereas the proportions of alcohol-attributable cancers were higher for upper aerodigestive tract cancers, the largest numbers of alcoholattributable cases were seen for colorectal and breast cancers. In the United Kingdom, about $4.0 \%$ of all cancers $(4.6 \%$ in men and $3.3 \%$ in women) were attributable to alcohol consumption. $^{24}$

Schütze and colleagues ${ }^{18}$ estimated that $10 \%$ of cancers in men and $3 \%$ of cancers in women in 6 European countries (Denmark, Germany, Greece, Italy, Spain and the United Kingdom) were attributable to alcohol consumption. These proportions are higher than those estimated for Alberta. Some of the difference may relate to the methods used to estimate the number of attributable cases: Schütze and colleagues ${ }^{18}$ derived relative risks directly from the European Prospective Investigation into Cancer and Nutrition, a large prospective cohort study conducted across 10 European countries that included 8 years of follow-up. Furthermore, those authors estimated alcohol consumption using a triangulation algorithm 


\section{OPEN}

Research

that combined information on alcohol consumption from survey data as reported to the World Health Organization and per-capita consumption data for males and females over age
15. For example, the estimated proportions of cancers attributable to alcohol in the United Kingdom were $8 \%$ in men and $3 \%$ in women. In addition, the fact that alcohol consumption

\section{Table 4: Observed cancer cases in Alberta in 2012 and proportions attributable to alcohol consumption}

\begin{tabular}{|c|c|c|c|c|c|c|c|c|c|c|}
\hline $\begin{array}{l}\text { Age at } \\
\text { exposure, } \\
\text { yr }\end{array}$ & $\begin{array}{c}\text { Age at } \\
\text { outcome, } \\
y r\end{array}$ & \multicolumn{3}{|c|}{ Larynx } & \multicolumn{3}{|c|}{ Colorectum } & \multicolumn{3}{|c|}{ Liver } \\
\hline \multicolumn{11}{|l|}{ Men } \\
\hline $20-34$ & $30-44$ & $<5$ & $\begin{array}{c}19.4 \\
(17.6-21.4)\end{array}$ & 0 & 37 & $\begin{array}{c}7.9 \\
(4.9-12.8)\end{array}$ & $3(2-5)$ & $<5$ & $\begin{array}{c}7.9 \\
(5.9-11.3)\end{array}$ & 0 \\
\hline $50-64$ & $60-74$ & 37 & $\begin{array}{c}13 \\
(11.8-14.2)\end{array}$ & $5(4-5)$ & 454 & $\begin{array}{c}5.4 \\
(3.4-8.6)\end{array}$ & $25(15-39)$ & 54 & $\begin{array}{c}5.5 \\
(4.0-7.7)\end{array}$ & $3(2-4)$ \\
\hline$\geq 65$ & $\geq 75$ & 7 & $\begin{array}{c}8.6 \\
(7.8-9.4)\end{array}$ & $1(1-1)$ & 338 & $\begin{array}{c}4.5 \\
(2.8-7.2)\end{array}$ & $15(9-24)$ & 34 & $\begin{array}{c}3.6 \\
(2.6-5.0)\end{array}$ & $1(1-2)$ \\
\hline Total & & $<67$ & & 8 & 1105 & & 60 & $<151$ & & 8 \\
\hline $35-49$ & $45-59$ & $<5$ & $\begin{array}{c}5.3 \\
(4.8-5.8)\end{array}$ & 0 & 193 & $\begin{array}{c}2.9 \\
(1.8-4.7)\end{array}$ & $6(3-9)$ & 17 & $\begin{array}{c}2.2 \\
(1.6-3.1)\end{array}$ & $0(0-1)$ \\
\hline $50-64$ & $60-74$ & 6 & $\begin{array}{c}5.2 \\
(4.9-5.5)\end{array}$ & $0(0-0)$ & 292 & $\begin{array}{c}2.3 \\
(1.4-3.6)\end{array}$ & $7(4-11)$ & 32 & $\begin{array}{c}2.2 \\
(1.5-3.1)\end{array}$ & $1(1-1)$ \\
\hline$\geq 65$ & $\geq 75$ & 5 & $\begin{array}{c}3.3 \\
(3.0-3.7)\end{array}$ & $0(0-0)$ & 326 & $\begin{array}{c}1.3 \\
(0.9-2.2)\end{array}$ & $4(3-7)$ & 18 & $\begin{array}{c}1.4 \\
(1.0-1.9)\end{array}$ & $0(0-0)$ \\
\hline \multirow[t]{2}{*}{ Total } & & $<16$ & & 0 & 846 & & 18 & $<72$ & & 1 \\
\hline & & \multicolumn{3}{|c|}{ Esophagus } & \multicolumn{3}{|c|}{ Oral cavity and pharynx } & \multicolumn{3}{|c|}{ Breast } \\
\hline $\begin{array}{l}\text { Age at } \\
\text { exposure, } \\
\text { yr }\end{array}$ & $\begin{array}{c}\text { Age at } \\
\text { outcome, } \\
y r\end{array}$ & $\begin{array}{c}\text { No. of } \\
\text { cases } \\
\text { observed }\end{array}$ & $\begin{array}{c}\text { PAR, \% } \\
(95 \% \mathrm{Cl})\end{array}$ & $\begin{array}{c}\text { No. of } \\
\text { EACs } \\
(95 \% \mathrm{Cl})^{*}\end{array}$ & $\begin{array}{c}\text { No. of } \\
\text { cases } \\
\text { observed }\end{array}$ & $\begin{array}{c}\text { PAR, \% } \\
(95 \% \mathrm{Cl})\end{array}$ & $\begin{array}{c}\text { No. of } \\
\text { EACs } \\
\left(95 \% \mathrm{Cl}^{*}\right)\end{array}$ & $\begin{array}{c}\text { No. of } \\
\text { cases } \\
\text { observed }\end{array}$ & $\begin{array}{l}\text { PAR, \% } \\
(95 \% \text { Cl) }\end{array}$ & $\begin{array}{c}\text { No. of } \\
\text { EACs } \\
(95 \% \mathrm{Cl})\end{array}$ \\
\hline$\geq 65$ & $\geq 75$ & 37 & $\begin{array}{c}10.5 \\
(9.8-11.2)\end{array}$ & $4(4-4)$ & 34 & $\begin{array}{c}15.8 \\
(14.7-17.0)\end{array}$ & $5(5-6)$ & - & - & - \\
\hline Total & & $<152$ & & $<24$ & 273 & & 54 & - & & - \\
\hline \multicolumn{11}{|l|}{ Women } \\
\hline $20-34$ & $30-44$ & $<5$ & $\begin{array}{c}6.9 \\
(6.5-7.4)\end{array}$ & 0 & 12 & $\begin{array}{c}10.3 \\
(9.6-11.0)\end{array}$ & $1(1-1)$ & 257 & $\begin{array}{c}3.7 \\
(2.9-4.7)\end{array}$ & $9(7-12)$ \\
\hline $35-49$ & $45-59$ & 9 & $\begin{array}{c}6.9 \\
(6.4-7.3)\end{array}$ & $1(1-1)$ & 22 & $\begin{array}{c}10.3 \\
(9.6-11.1)\end{array}$ & $2(2-2)$ & 798 & $\begin{array}{c}3.6 \\
(2.9-4.5)\end{array}$ & $29(23-36)$ \\
\hline $50-64$ & $60-74$ & 15 & $\begin{array}{c}5.2 \\
(4.9-5.5)\end{array}$ & $1(1-1)$ & 34 & $7.6(7.1-8.2)$ & $3(2-3)$ & 840 & $\begin{array}{c}2.8 \\
(2.2-3.5)\end{array}$ & $23(18-29)$ \\
\hline$\geq 65$ & $\geq 75$ & 7 & $\begin{array}{c}3.1 \\
(2.9-3.3)\end{array}$ & $0(0-0)$ & 32 & $\begin{array}{c}4.6 \\
(4.3-4.9)\end{array}$ & $1(1-2)$ & 427 & $\begin{array}{c}1.7 \\
(1.3-2.1)\end{array}$ & $7(6-9)$ \\
\hline Total & & $<36$ & & 2 & 100 & & 8 & 2322 & & 69 \\
\hline
\end{tabular}


Table 5: Summary of cases and proportions of cancers attributable to alcohol consumption

\begin{tabular}{|c|c|c|c|c|c|c|c|c|c|}
\hline \multirow[b]{2}{*}{ Cancer site† } & \multicolumn{3}{|c|}{ Total } & \multicolumn{3}{|c|}{ Men } & \multicolumn{3}{|c|}{ Women } \\
\hline & $\begin{array}{l}\text { No. of } \\
\text { cases } \\
\text { observed }\end{array}$ & $\begin{array}{c}\text { No. of } \\
\text { excess } \\
\text { attributable } \\
\text { cases }^{*}\end{array}$ & $\begin{array}{c}\% \\
\text { attributable† }\end{array}$ & $\begin{array}{c}\text { No. of } \\
\text { cases } \\
\text { observed }\end{array}$ & $\begin{array}{c}\text { No. of } \\
\text { excess } \\
\text { attributable } \\
\text { cases* }^{*}\end{array}$ & $\begin{array}{c}\% \\
\text { attributable† }\end{array}$ & $\begin{array}{c}\text { No. of } \\
\text { cases } \\
\text { observed }\end{array}$ & $\begin{array}{c}\text { No. of } \\
\text { excess } \\
\text { attributable } \\
\text { cases* }^{*}\end{array}$ & $\begin{array}{c}\% \\
\text { attributable† }\end{array}$ \\
\hline Breast & 2322 & 69 & 3.0 & - & - & - & 2322 & 69 & 3.0 \\
\hline Larynx & 76 & 9 & 11.8 & 64 & 8 & 12.5 & 12 & 1 & 8.3 \\
\hline Colorectum & 1951 & 77 & 3.9 & 1105 & 60 & 5.4 & 846 & 18 & 2.1 \\
\hline Liver & 217 & 9 & 4.1 & 148 & 8 & 5.4 & 69 & 1 & 1.4 \\
\hline Esophagus & 183 & 21 & 11.5 & 151 & 19 & 12.6 & 32 & 2 & 6.2 \\
\hline $\begin{array}{l}\text { Oral cavity and } \\
\text { pharynx }\end{array}$ & 373 & 62 & 16.6 & 273 & 54 & 19.8 & 100 & 8 & 8.0 \\
\hline $\begin{array}{l}\text { All associated } \\
\text { cancers } \ddagger\end{array}$ & 51 & 247 & 4.8 & 1741 & 149 & 8.6 & 3381 & 99 & 2.9 \\
\hline All cancers§ & 15836 & 247 & 1.6 & 8155 & 149 & 1.8 & 7681 & 99 & 1.3 \\
\hline
\end{tabular}

levels were higher in the European countries ${ }^{18}$ than in Alberta may also explain some of the observed differences in the proportions of alcohol-attributable cancers between the analyses.

\section{Limitations}

Because data from population surveys such as the Canadian Community Health Survey tend to underestimate true alcohol consumption levels, ${ }^{30}$ estimates of population attributable risk using these data are also likely underestimates of the true alcohol-attributable cancer burden. To address this limitation, we attempted to adjust for this undercoverage using alcohol sales data for Alberta from Statistics Canada to characterize recorded alcohol consumption. With this adjustment, the proportion of cancers attributable to alcohol consumption increased from $1.6 \%$ to $3.5 \%$. In addition, a portion of consumption from sources such as home-brewing or illegal imports is unrecorded and needs to be accounted for when estimating population alcohol exposure levels., ${ }^{5,31}$ After adjustment for these other sources of alcohol intake, there was a further increase in the proportion of alcohol-attributable cancers, to $4.2 \%$. However, because data for unrecorded alcohol consumption do not exist in Alberta, we used Ontario estimates. This additional adjustment may have resulted in either an under- or overestimate of the true proportion of cancers attributable to alcohol consumption, depending on whether actual unrecorded alcohol consumption levels are higher or lower in Alberta than in Ontario. Error associated with this assumption represents a potential limitation of our work.

A further limitation was our assumption that the appropriate period between exposure and cancer incidence (referred to as the latency period) was the midpoint of observed follow-up times between exposure assessment and cancer incidence in large cohort studies. Because we did not have access to data concerning alcohol consumption with the same level of detail as was included in Canadian Community Health Survey data for years before 2000, we were unable to conduct sensitivity analyses to investigate whether choosing longer latency periods would have influenced our estimated population attributable risks. Specifically, if the use of a different latency period suggested that alcohol consumption levels in Alberta were higher or lower than those observed with our chosen latency period, our estimates of population attributable risk would represent under- or overestimates, respectively.

\section{Conclusion}

No level of alcohol consumption is considered safe with respect to cancer risk, and alcohol consumption represents a modifiable cancer risk factor. As such, with as much as $4.2 \%$ of cancers in Alberta potentially attributable to alcohol consumption, strategies to reduce alcohol consumption have the potential to reduce Alberta's cancer burden.

\section{References}

1. IARC monographs on the evaluation of carcinogenic risks to bumans: alcohol drinking. Vol 44. Lyon (France): International Agency for Research on Cancer; 1988.

2. IARC monographs on the evaluation of carcinogenic risks to bumans: alcohol consumption and ethyl carbamate. Vol 96. Lyon (France): International Agency for Research on Cancer; 2010.

3. World Cancer Research Fund/American Institute for Cancer Research. Food nutrition, physical activity, and the prevention of cancer: a global perspective. Washington: American Institute for Cancer Research; 2007.

4. Boffetta P, Hashibe M. Alcohol and cancer. Lancet Oncol 2006;7:149-56.

5. Cancer risk factors in Ontario: alcohol. Toronto: Cancer Care Ontario; 2014.

6. Grundy A, Friedenreich CM, Poirier AE, et al. A methodologic framework to evaluate the number of cancers attributable to lifestyle and environment in Alberta. CMA7 Open 2016 Sept. 15;4(3):E471-8.

7. Allen NE, Beral V, Casabonne D, et al. Moderate alcohol intake and cancer incidence in women. 7 Natl Cancer Inst 2009;101:296-305.

8. Bakken K, Fournier A, Lund E, et al. Menopausal hormone therapy and breast cancer risk: impact of different treatments. European Prospective Investigation into Cancer and Nutrition. Int 7 Cancer 2011;128:144-56.

9. Brinton LA, Richesson D, Leitzmann MF, et al. Menopausal hormone therapy and breast cancer risk in the NIH-AARP Diet and Health Study Cohort. Cancer Epidemiol Biomarkers Prev 2008;17:3150-60. 
10. Chen WY, Rosner B, Hankinson SE, et al. Moderate alcohol consumption during adult life, drinking patterns, and breast cancer. FAMA 2011;306: 1884-90.

11. Cho E, Lee JE, Rimm EB, et al. Alcohol consumption and the risk of colon cancer by family history of colorectal cancer. Am 7 Clin Nutr 2012;95:413-9.

12. Freedman ND, Schatzkin A, Leitzmann MF, et al. Alcohol and head and neck cancer risk in a prospective study. Br 7 Cancer 2007;96:1469-74.

13. Ishiguro S, Sasazuki S, Inoue $M$, et al. Effect of alcohol consumption, cigarette smoking and flushing response on esophageal cancer risk: a population based cohort study (JPHC study). Cancer Lett 2009;275:240-6.

14. Koh WP, Robien K, Wang R, et al. Smoking as an independent risk factor for hepatocellular carcinoma: the Singapore Chinese Health Study. Br 7 Cancer 2011;105:1430-5.

15. Maasland DH, van den Brandt PA, Kremer B, et al. Alcohol consumption, cigarette smoking and the risk of subtypes of head-neck cancer: results from the Netherlands Cohort Study. BMC Cancer 2014;14:187.

16. Persson EC, Schwartz LM, Park Y, et al. Alcohol consumption, folate intake, hepatocellular carcinoma, and liver disease mortality. Cancer Epidemiol Biomarkers Prev 2013;22:415-21.

17. Razzak AA, Oxentenko AS, Vierkant RA, et al. Alcohol intake and colorectal cancer risk by molecularly defined subtypes in a prospective study of older women. Cancer Prev Res (Phila) 2011;4:2035-43.

18. Schütze M, Boeing H, Pischon T, et al. Alcohol attributable burden of incidence of cancer in eight European countries based on results from prospective cohort study. BM7 2011;342:d1584.

19. Shin A, Joo J, Bak J, et al. Site-specific risk factors for colorectal cancer in a Korean population. PLoS One 2011;6:e23196.

20. Tran GD, Sun XD, Abnet CC, et al. Prospective study of risk factors for esophageal and gastric cancers in the Linxian general population trial cohort in China. Int 7 Cancer 2005;113:456-63.

21. Weikert C, Dietrich T, Boeing H, et al. Lifetime and baseline alcohol intake and risk of cancer of the upper aero-digestive tract in the European Prospective Investigation into Cancer and Nutrition (EPIC) study. Int 7 Cancer 2009;125: 406-12.

22. Statistics Canada. Canadian Community Health Survey - methodological overview. Health Rep 2002;13:9-14.

23. About alcobol. Toronto: Centre for Addiction and Mental Health; 2012. Available: www.camh.ca/en/hospital/health_information/a_z_mental_health_and addiction_information/alcohol/Pages/about_alcohol.aspx (accessed 2015 Jan. 5).

24. Parkin DM. 3. Cancers attributable to consumption of alcohol in the UK in 2010. Br 7 Cancer 2011;105:S14-8.

25. Hamajima N, Hirose K, Tajima K, et al.; Collaborative Group on Hormonal Factors in Breast Cancer. Alcohol, tobacco and breast cancer - collaborative reanalysis of individual data from 53 epidemiological studies, including 58,515 women with breast cancer and 95,067 women without the disease. Br 7 Cancer 2002;87:1234-45

26. Corrao G, Bagnardi V, Zambon A, et al. A meta-analysis of alcohol consumption and the risk of 15 diseases. Prev Med 2004;38:613-9.

27. Ferrari P, Jenab M, Norat T, et al. Lifetime and baseline alcohol intake and risk of colon and rectal cancers in the European Prospective Investigation into Cancer and Nutrition (EPIC). Int 7 Cancer 2007;121:2065-72.
28. Renehan AG, Soerjomataram I, Tyson M, et al. Incident cancer burden attributable to excess body mass index in 30 European countries. Int 7 Cancer 2010; 126:692-702.

29. Lee IM, Shiroma EJ, Lobelo F, et al.; Lancet Physical Activity Series Working Group. Effect of physical inactivity on major non-communicable diseases worldwide: an analysis of burden of disease and life expectancy. Lancet 2012; 380:219-29

30. Shield KD, Kehoe T, Taylor B, et al. Alcohol-attributable burden of disease and injury in Canada, 2004. Int F Public Health 2012;57:391-401.

31. Macdonald S, Wells S, Giesbrecht N. Unrecorded alcohol consumption in Ontario, Canada: estimation procedures and research implications. Drug Alcobol Rev 1999;18:21-9.

Affiliations: Department of Cancer Epidemiology and Prevention Research (Grundy, Poirier, Khandwala, McFadden, Friedenreich, Brenner), CancerControl Alberta; Department of Oncology (Friedenreich, Brenner); Department of Community Health Sciences (Friedenreich, Brenner), Cumming School of Medicine, University of Calgary, Calgary, Alta.

Contributors: Christine Friedenreich and Darren Brenner were responsible for study conception. Anne Grundy, Abbey Poirier, Farah Khandwala, Christine Friedenreich and Darren Brenner contributed substantially to study design and interpretation of the data. Anne Grundy and Alison McFadden were responsible for data acquisition, and Farah Khandwala completed the analysis. All of the authors contributed to drafting and revising the manuscript, approved the final version to be published and agreed to act as guarantors of the work.

Funding: This project was funded by the Alberta Cancer Prevention Legacy Fund. Christine Friedenreich is supported by an Alberta Innovates - Health Solutions Health Senior Scholar Award and the Alberta Cancer Foundation Weekend to End Women's Cancers Breast Cancer Chair at the University of Calgary. Darren Brenner is supported by a Career Development Award in Prevention from the Canadian Cancer Society Research Institute.

Acknowledgements: The authors gratefully acknowledge Laura McDougall from the Alberta Cancer Prevention Legacy Fund for her support and guidance. They also thank Bethany Kaposhi and Lorraine Shack from the Alberta Cancer Registry for providing cancer incidence data, the Department of Data Integration, Measurement and Reporting at Alberta Health Services for access to Canadian Community Health Survey data and Eileen Shaw for critical review of the manuscript.

Supplemental information: For reviewer comments and the original submission of this manuscript, please see www.cmajopen.ca/content $/ 4 / 3 /$ E507/suppl/DC1 